\title{
Analisis Kadar Vitamin C Pada Daun Katuk (Sauropus Androgynus) Segar, Direbus dan Dikukus Dengan Metode Spektrofotometri UV-Vis
}

\author{
Muhammad Hadi Sulhan
}

\begin{abstract}
Abstrak
Daun katuk merupakan sejenis sayuran daun hijau yang memiliki banyak manfaat bagi masyarakat salah satunya untuk mengobati sakit maag, demam, sakit telinga, dan frambenis. Vitamin yang terkandung dalam daun katuk dan berguna bagi tubuh, salah satunya adalah vitamin C. Vitamin $\mathrm{C}$ memiliki sifat yang mudah rusak terhadap panas, dan mudah larut dalam air. Penelitian ini bertujuan untuk melihat kadar vitamin $\mathrm{C}$ pada daun katuk segar, dikukus, dan direbus dengan metode Spektrofotometri UV-Vis. Penentuan kadar vitamin C dengan metode ini sangat relatif murah dan baik. Hasil yang didapatkan dengan 30 sampel dengan rata-rata kadar vitamin $\mathrm{C}$ pada daun katuk segar $0,0036 \%$, daun katuk dikukus 0 , dan daun katuk direbus $0,0032 \%$. Maka dapat disimpulkan bahwa kadar vitamin $\mathrm{C}$ daun katuk yang direbus tidak terjadi penurunakan kadar yang signifikan dibandingkan dengan kadar Vitamin C pada daun katuk segar berbeda dengan daun katuk yang di kukus kadar vitamin C menjadi tidak ada.
\end{abstract}

Kata kunci : Vitamin C, daun katuk, Spektrofotometri UV-Vis

\section{Abstract}

Katuk leaf (Sauropus Androgynus) is a kind of green leafy vegetable which has many benefits for the community, one of which is to treat heartburn, fever, earache, and yaws. Vitamins contained in Sauropus Androgynus and are useful for the body, one of which is vitamin $C$. Vitamin $C$ has properties that are easily damaged against heat, and easily dissolve in water. This study aims to look at vitamin C levels in fresh, steamed and boiled Sauropus Androgynus by the UV-Vis Spectrophotometry method. Determination of vitamin C levels with this method is relatively inexpensive and good in accuracy. The results obtained with 30 samples with an average level of vitamin $C$ in fresh Sauropus Androgynus 0.0036\%, Sauropus Androgynus steamed 0, and Sauropus Androgynus boiled 0.0032\%. It can be concluded that the vitamin C levels of boiled Sauropus Androgynus do not decrease significantly, compared to the levels of Vitamin $C$ on freshSauropus Androgynus. the result is different from the Sauropus Androgynus that are steamed vitamin C levels become zero $\mathrm{mg}$.

Keywords: Vitamin C, Sauropus androgynus, Spectrophotometer UV-Vis

\section{PENDAHULUAN}

Vitamin $\mathrm{C}$ atau asam askorbat merupakan zat yang sangat dibutuhkan oleh tubuh yang telah banyak diketahui dapat berperan sebagai zat anti oksidan (Cimmino, 2018). Kekurangan vitamin C biasanya menyebabkan penyakit scurvy atau skorbut. Skorbut ditandai dengan adanya pembengkakan dan perdarahan pada gusi, gingivalis, kaki menjadi empuk, anemia, dan deformasi tulang (Padayatty, 2016).

Vitamin $\mathrm{C}$ atau asam askorbat mempunyai berat molekul $176 \mathrm{~g} / \mathrm{mol}$ dengan rumus molekul $\mathrm{C}_{6} \mathrm{H}_{8} \mathrm{O}_{6}$. Vitamin $\mathrm{C}$ dalam bentuk kristal tidak berwarna dengan titic cair pada suhu $190-192^{\circ} \mathrm{C}$. 
Vitamin C juga larut dalam air dan sedikit larut dalam aseton atau alkohol yang mempunyai berat molekul rendah. Vitamin C sukar larut dalam kloroform, eter, dan benzen.

Vitamin $\mathrm{C}$ dapat kita temukan pada seluruh tanaman dan sebagain besar hewan (Smirnoff, 2001). Vitamin C tidak dapat dihasilkan oleh tubuh manusia dikarenakan tidak adanya enzim dalam tubuh yang dapat menghasilkan zat gulonolakton oksidase untuk mensintesis vitamin $\mathrm{C}$ (Linster, 2007). Oleh karena itu manusia memerlukan sumber vitamin $\mathrm{C}$ dari luar yaitu dari tumbuh-tumbuhn dan sebagain besar hewan untuk memenuhi kebutuhan vitamin $\mathrm{C}$ dalam tubuhnya.

Tanaman sebagai sumber vitamin $\mathrm{C}$ sebagian besar berasal dari sayuran dan buah-buahan, terutama buah-buahan segar. Buah yang masih mentah lebih banyak kandungan vitamin C-nya, semakin tua buah semakin berkurang kandungan vitamin C-nya (Winarno, 1992).

Pada sayuran seperti bayam, brokoli, cabe merah, kubis, dan dauk katuk juga merupakan sumber vitamin $\mathrm{C}$ yang baik. Katuk adalah sejenis sayuran daun. Tanaman dengan nama latin Sauropus adrogynus termasuk famili Euphorbiaceae (Malik, 1997). Tanaman ini sebagian besar ditanam di Asia Selatan dan Asia Tenggara. Selain itu, ini biasanya digunakan sebagai obat tradisional untuk memurnikan darah, demam, maag, masalah kencing, sakit telinga dan frambenis. Ekstrak S. androgynus dapat menstimulasi berat badan, serta mengurangi kadar kolesterol. Rukmana (2003) dalam penelitiannya menemukan bahwa daun katuk selain mengandung flavanoid juga mengandung vitain C. Setelah dilakukan uji pendahuluan (uji kualitatif) di laboratorium kimia terapan D3 Analis Kesehatan dengan mengambil sampel pada daun katuk yang segar, direbus, dan dikukus dengan menggunakan zat betadin. Hasil positif pada sampel segar, direbus dan dikukus berubah warna menjadi hijau pekat setelah ditetesi larutan betadin sebanyak 3 tetes. Hal ini menunjukan bahwa pada ketiga sampel tersebut positif mengandung vitamin $\mathrm{C}$.

Pengolahan tanaman sayuran biasanya dilakukan dengan cara direbus ataupun dikukus. Proses pengolahan seperti ini memerlukan suhu di atas $80^{\circ} \mathrm{C}$. Penggunaan suhu yang tinggi pada proses pengolahan sayuran akan berdampak pada kadar zat-zat yang terkandung didalam sayuran tersebut tidak terkecuali kandungan vitamin C. Hal ini seperti yang diungkapkan oleh Winarno (1992) bahwa vitamin $\mathrm{C}$ mudah sekali rusak oleh adanya panas.

Kadar vitamin C dapat ditentukan dengan beberapa metode seperti titrasi iodimetri, titrasi 2,6-diklorofenol indofenol dan secara spektrofotometri UV-Vis. Metode spektrofotometri dapat digunakan 
untuk penetapan kadar campuran dengan spektrum yang tumpang tindih tanpa pemisahan terlebih dahulu. Karena perangkat lunaknya mudah digunakan untuk instrumentasi analisis dan mikrokomputer, spektrofotometri banyak digunakan di berbagai bidang analisis kimia terutama farmasi (Munson, 1991).

Berdasarkan uraian diatas, maka penulis tertarik untuk melakukan penelitian dengan judul "Analisis Kadar Vitamin C pada Daun Katuk (Sauropus Androgynus) segar, direbus, dan dikukus dengan metode Spektrofotometri UV-Vis.

\section{METODE PENELITIAN}

\section{Alat}

Alat-alat yang digunakan adalah timbangan analitik, corong, spatel, kertas saring Whatma, labu ukur, gelas ukur, cawan penguap, beaker glass, erlemeyer, batang pengaduk, pipet mikro,dan seperangkat alat spektrofotometer UVVisibel.

\section{Bahan}

bahan yang digunakan adalah daun katuk (Sauropus Androgynus), asam askorbat, asan oksalat 0,4\%, ammonium molibdat $5 \%, \mathrm{H}_{2} \mathrm{SO}_{4} 5 \%$, aquadest.

\section{Pengambilan Sampel}

Sampel yang digunakan adalah daun katuk (Sauropus Androgynus) yang diambil dari daerah Cikajang-garut.

\section{Identifikasi Sampel}

Identifikasi sampel dilakukan di Laboratorium Kimia Terapan D3 Analis Kesehatan STIKes Karsa Husada Garut kampus I.

\section{Uji kualitatif}

a. Ditimbang 2,5 gram sampel daun katuk yang sudah dihaluskan.

b. Kemudian, tambahkan $25 \mathrm{ml}$ aquadest dan homogenkan.

c. Masukkan $\pm 5 \mathrm{~mL}$ sampel ke dalam tabung reaksi dan tambahkan 5 tetes amilum, lalu homogenkan.

d. Tambahkan beberapa tetes betadine sampai berubah warna.

\section{Pembuatan larutan induk vitamin $C$ 1000 Ppm}

Asam askorbat ditimbang sebanyak $25 \mathrm{mg}$ kemudian dimasukkan ke dalam labu ukur $25 \mathrm{~mL}$ dan dilarutkan dengan asam oksalat $0,4 \%$ hingga tanda batas (1000 ppm), kemudian diencerkan sebanyak 10x (100 ppm).

\section{Penentuan panjang gelombang maksi mum larutan vitamin $\mathbf{C}$}

Dipipet $0,8 \mathrm{~mL}$ larutan vitamin $\mathrm{C}$ (100 ppm), lalu dimasukkan ke dalam labu ukur $100 \mathrm{~mL}$, kemudian ditambahkan $\mathrm{H}_{2} \mathrm{SO}_{4} \quad 5 \%$ sebanyak $5 \mathrm{~mL}$, kemudian ditambahkan ammonium molibdat 5\% sampai tanda batas dan dihomogenkan. Diinkubasi selama 30 menit, lalu diukur serapannya dengan spektrofotometri UV- 
Visible pada rentang panjang gelombang $530-590 \mathrm{~nm}$.

\section{Pembuatan kurva kalibrasi}

Larutan vitamin C 100 ppm dipipet dan dimasukkan ke dalam labu ukur $25 \mathrm{~mL}$ masing-masing sebesar $0,5 \mathrm{~mL}, 1 \mathrm{~mL}, 1,5$ mL, $2 \mathrm{~mL}, 2,5 \mathrm{~mL}$ (2 ppm, 4 ppm, 6 ppm, 8 ppm, 10 ppm). Masing-masing larutan ditambahkan $\mathrm{H}_{2} \mathrm{SO}_{4} \quad 5 \%$ sebanyak $5 \mathrm{~mL}$ lalu dicukupkan volumenya dengan ammonium molibdat 5\% sampai tanda batas, dikocok dan dihomogenkan. Kemudian diinkubasi selama 30 menit. Diukur dengan spektrofotometri UVVisible pada panjang gelombang $550 \mathrm{~nm}$.

\section{Penentuan kadar sampel}

Daun katuk dicuci dengan bersih kemudian dihaluskan dengan blender sampai halus. Timbang sebanyak 1 gram serbuk daun katuk masukkan kedalam erlenmeyer $25 \mathrm{~mL}$ dan tambahkan aquadest $25 \mathrm{~mL}$ lalu diinkubasi selama 15 menit kemudian disaring menggunakan kertas whatman. Selanjutnya diukur serapannya pada panjang gelombang maksimum yang didapat.

\section{Penentuan Kadar Vitamin C dengan Spektrofotometri UV-Vis}

Data kurva kalibrasi menggunakan alat Spektrofotometer UV-Vis diolah dengan microsoft excel untuk menentukan persamaan linier kurva kalibrasi. Persamaan regresi linier yaitu $y=a x+b$, yang berarti y adalah absorbansi, $a$ dan $b$ adalah slope dan x merupakan konsentrasi sampel. Persamaan linier dapat digunakan untuk menentukan konsentrasi sampel tersebut dalam satuan ppm kemudian di konversikan ke mg.

\section{Uji Normalitas dan Uji Beda dengan program SPSS}

Pertama dilakukan uji normalitas dengan menggunakan metode ShaproWilk, kemudian setelah diketahui datanya normal atau tidak dilakukan uji beda. Metode uji beda yang digunakan apabila data normal dengan uji parametrik sedangkan apabila data tidak normal dilakukan uji non parametrik MannWhitney U.

\section{HASIL DAN PEMBAHASAN}

Hasil uji kualitatif vitamin C pada daun katuk segar, daun katuk setelah direbus dan daun katuk setelah dikukus ditunjukkan oleh gambar di bawah ini:

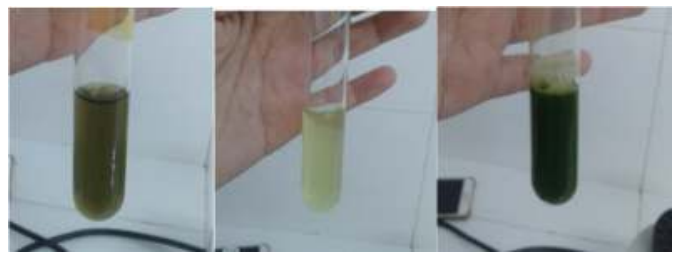

(a)

(b)

(c)

Gambar 1. Hasi uji kualitatif dengan metode betadin, (a) daun katuk direbus, (b) daun katuk dikukus, (c) daun katuk segar

Berdasarkan gambar 1. diketahui bahwa setelah penambahan betadin larutan yang awalnya benih berubah menjadi hijau. Hal ini menandakan adanya kandungan vitamin $\mathrm{C}$ pada ketiga sampel. 
Warna hijau pada sampel diakibatkan oleh reaksi yang terjadi antara iodin dengan indikator amilum. Iodin dapat bereaksi dengan indikator amilum setelah habis bereaksi dengan vitamin $\mathrm{C}$ yang ada pada sampel sesuai reaksi di bawah ini:

$\mathrm{C}_{6} \mathrm{H}_{8} \mathrm{O}_{6}+\mathrm{I}_{2} \rightarrow \mathrm{C}_{6} \mathrm{H}_{6} \mathrm{O}_{6}+2 \mathrm{I}^{-}+2 \mathrm{H}^{+}$

Warna hijau paling pudar ditunjukkan oleh sampel daun katuk yang dikukus yang menandakan bahwa kandungan vitamin $\mathrm{C}$ nya sudah jauh berkurang.

Pengujian selanjutnya dilakukan uji kuantitatif dengan metode spektrofotometri untuk mengetahui kadar vitamin $\mathrm{C}$ yang terdapat pada daun katuk segar, daun katuk setelah direbus dan daun katuk setelah dikukus. Penentuan vitamin C menggunakan spekrofotometer menghasilkan nilai bsorbansi yang ditunjukkan oleh tabel di bawah ini:

Tabel 1. Absorbansi daun katuk segar, direbus dan dikukus (gram)

\begin{tabular}{cccc}
\hline No & $\begin{array}{l}\text { Daun } \\
\text { katuk } \\
\text { segar }\end{array}$ & $\begin{array}{l}\text { Daun } \\
\text { katuk } \\
\text { dikukus }\end{array}$ & $\begin{array}{l}\text { Daun } \\
\text { katuk } \\
\text { direbus }\end{array}$ \\
\hline 1 & 0,554 & 0,081 & 0,864 \\
\hline 2 & 0,546 & 0,101 & 0,882 \\
\hline 3 & 0,538 & 0,071 & 0,886 \\
\hline 4 & 0,550 & 0,080 & 0,891 \\
\hline 5 & 0,557 & 0,083 & 0,890 \\
\hline 6 & 0,557 & 0,082 & 0,866 \\
\hline 7 & 0,549 & 0,102 & 0,883 \\
\hline 8 & 0,542 & 0,069 & 0,885 \\
\hline 9 & 0,552 & 0,079 & 0,893 \\
\hline 10 & 0,562 & 0,082 & 0,888 \\
\hline 11 & 0,946 & 0,059 & 0,611 \\
\hline
\end{tabular}

\begin{tabular}{cccc}
\hline 12 & 0,940 & 0,072 & 0,606 \\
\hline 13 & 0,935 & 0,070 & 0,614 \\
\hline 14 & 0,434 & 0,015 & 0,616 \\
\hline 15 & 0,954 & 0,069 & 0,616 \\
\hline 16 & 0,942 & 0,058 & 0,611 \\
\hline 17 & 0,935 & 0,071 & 0,606 \\
\hline 18 & 0,931 & 0,070 & 0,612 \\
\hline 19 & 0,435 & 0,015 & 0,615 \\
\hline 20 & 0,946 & 0,068 & 0,615 \\
\hline 21 & 0,606 & 0,065 & 0,495 \\
\hline 22 & 0,587 & 0,065 & 0,285 \\
\hline 23 & 0,662 & 0,066 & 0,505 \\
\hline 24 & 0,673 & 0,070 & 0,275 \\
\hline 25 & 0,663 & 0,068 & 0,509 \\
\hline 26 & 0,606 & 0,064 & 0,492 \\
\hline 27 & 0,586 & 0,063 & 0,287 \\
\hline 28 & 0,661 & 0,065 & 0,502 \\
\hline 29 & 0,673 & 0,690 & 0,275 \\
\hline 30 & 0,664 & 0,069 & 0,505 \\
\hline Rata2 & 0,6762 & 0,0894 & 0,6360 \\
\hline & & &
\end{tabular}

Tabel 1 menunjukkan nilai absorbansi 30 sampel pada daun katuk yang masih segar, daun katuk yang sudah direbus dan daun katuk yang sudah dikukus. Rata-rata absorbansi yang dihasilkan adalah 0,6762 untuk daun katuk yang masih segar, 0,0894 untuk daun katuk yang sudah dikukus dan 0,6360 untuk daun katuk yang sudah direbus. Nilai absorbansi pada sampel daun katuk yang sudah dikukus berkurang sampai 1/10 kali absorbansi daun katuk segar. Hal ini sejalan dengan hasil uji kualitatif yang menunjukkan intensitas warna pada sampel daun katuk setelah dikukus berwarna lebih pudar dari pada sampel daun katuk segar. Absorbansi sampel daun katuk yang sudah direbus dapat dikatakan tidak berbeda secara signifikan dengan absorbansi daun 
katuk segar. Hal ini akan dibuktikan dengan pengujian statistik yaitu uji beda setelah emngetahui kadar vitamin $\mathrm{C}$ yang terkandung di dalam masing-masing sampel.

Absorbansi yang dihasilkan pada tabel 1. digunakan untuk menentukan kadar vitamin $\mathrm{C}$ yang terkandung didalam daun katuk yang masih segar, daun katuk yang sudah dikukus dan daun katuk yang sudah direbus. Hasil konsentrasi yang dihasilkan ditunjukkan oleh tabel di bawah ini:

Tabel 2. Kadar Vitamin $C$ daun katuk segar, direbus dan dikukus (gram)

\begin{tabular}{cccc}
\hline No & $\begin{array}{c}\text { Daun } \\
\text { katuk } \\
\text { segar }\end{array}$ & $\begin{array}{c}\text { Daun } \\
\text { katuk } \\
\text { dikukus }\end{array}$ & $\begin{array}{c}\text { Daun } \\
\text { katuk } \\
\text { direbus }\end{array}$ \\
\hline 1 & 0,0214 & 0 & 0,0567 \\
\hline 2 & 0,0205 & 0 & 0,0588 \\
\hline 3 & 0,0196 & 0 & 0,0592 \\
\hline 4 & 0,0210 & 0 & 0,0598 \\
\hline 5 & 0,0218 & 0 & 0,0597 \\
\hline 6 & 0,0218 & 0 & 0,0570 \\
\hline 7 & 0,0209 & 0 & 0,0589 \\
\hline 8 & 0,0201 & 0 & 0,0591 \\
\hline 9 & 0,0212 & 0 & 0,0600 \\
\hline 10 & 0,0223 & 0 & 0,0595 \\
\hline 11 & 0,0661 & 0 & 0,0279 \\
\hline 12 & 0,0654 & 0 & 0,0274 \\
\hline 13 & 0,0648 & 0 & 0,0283 \\
\hline 14 & 0,0078 & 0 & 0,0285 \\
\hline 15 & 0,0670 & 0 & 0,0285 \\
\hline 16 & 0,0656 & 0 & 0,0279 \\
\hline 17 & 0,0648 & 0 & 0,0274 \\
\hline 18 & 0,0644 & 0 & 0,0280 \\
\hline 19 & 0,0079 & 0 & 0,0284 \\
\hline 20 & 0,0661 & 0 & 0,0284 \\
\hline 21 & 0,0274 & 0 & 0,0147 \\
\hline 22 & 0,0252 & 0 & 0 \\
\hline & & & \\
\hline
\end{tabular}

\begin{tabular}{cccc}
\hline 23 & 0,0337 & 0 & 0,0159 \\
\hline 24 & 0,0350 & 0 & 0 \\
\hline 25 & 0,0338 & 0 & 0,0163 \\
\hline 26 & 0,0274 & 0 & 0,0144 \\
\hline 27 & 0,0251 & 0 & 0 \\
\hline 28 & 0,0336 & 0 & 0,0155 \\
\hline 29 & 0,0350 & 0 & 0 \\
\hline 30 & 0,0340 & 0 & 0,0159 \\
\hline Rata2 & 0,0354 & 0 & 0,0321
\end{tabular}

berdasarkan tabel 2 menunjukkan bahwa rata-rata kadar vitamin $\mathrm{C}$ pada daun katuk yang yang masih segar adalah 0,0354 gram. Kadar vitamin $\mathrm{C}$ pada daun katuk yang sudah dikukus adalah 0 . Sedangkan kadar vitamin C pada daun katuk yang sudah direbus adalah 0,0321 gram. Kadar vitamin $\mathrm{C}$ pada daun katuk yang sudah dikukus tercantum 0 dikarenakan absorbansi yang dihasilkan pada tabel 1. Diluar batas deteksi spektrofotometri UV-Vis yang digunakan. Sehingga hasil perhitungan konsentrasi pada sampel daun katuk yang dikukus dapat dikatakan 0 gram. Hasil perhitungan konsentrasi pada sampel daun katuk yang dikukus sejalan dengan hasil uji sebelumnya yaitu pada uji kualitatif warna yang dihasilkan jauh lebih pudar dibandingkan kedua sampel yang lain yaitu sampel daun katuk segar dan daun katuk yang direbus.

Selisih kadar vitamin C pada daun katuk segar dengan kadar vitamin C pada daun katuk yang sudah direbus adalah 0,0033 gram atau dengan kata lain sebesar 3,3 mg. Selisih kadar vitamin $\mathrm{C}$ tersebut 
dapat dikatakan sangat kecil. Pengujian seberapa besar tingkat perbedaan hasil pengukuran kadar vitamin $\mathrm{C}$ pada daun katuk yang segar dengan daun katuk yang direbus dapat dilakukan uji statistik. Uji statistik menghitung signifikasi perbedaan dua kelompok sampel dapat dilakukan dengan uji $\mathrm{T}$ apabila data berdistribusi normal dan Mann-Whitney apabila data tidak berdistribusi normal.

Pengujian signifikasi perbedaan pada dua kelompok sampel dapat dilakukan setelah mengetahui distribusi data pada setiap sampel. Distribusi data pada sampel tersebut dapat diketahui dengan melakukan uji normalitas data. Uji normalitas data yang digunakan adalah Shapiro-Wilk test. Pada pengujian normalitas data dengan Shapiro-Wilk test dapat diketahui dengan menentukan nilai signifikan dari data yang diuji. Dengan $\alpha=0,05$ maka apabila signifikansi yang didapatkan lebih besar dari nilai $\alpha$ maka dapat dikatakan data tersebut berdistribusi normal. Sebaliknya apabila nilai signifikansi lebih rendah dari pada nilai $\alpha$ maka dapat dikatakan bahwa data tersebut tidak berdistribusi normal.

Hasil pengujian normalitas data kadar vitamin $\mathrm{C}$ pada daun katuk yang segar dan daun katub yang sudah direbus dengan Shapiro-Wilk test ditunjukkan oleh tabel di bawah ini:

\section{Tabel 3. Uji normalitas data}

\begin{tabular}{|c|c|c|c|}
\hline & & $\begin{array}{c}\text { Kolmogorov } \\
\text {-Smirnov }\end{array}$ & $\begin{array}{c}\text { Shapiro- } \\
\text { Wilk }\end{array}$ \\
\hline \multirow{3}{*}{$\begin{array}{l}\text { konsent } \\
\text { rasi }\end{array}$} & kelompok & Sig. & Sig. \\
\hline & Segar & .000 & .000 \\
\hline & rebus & .002 & .002 \\
\hline
\end{tabular}

Hasil uji normalitas data daun katuk yang segar dengan daun katuk yang direbus menunjukkan signifikansi sebesar 0,00 untuk daun katuk segar dan 0,002 untuk daun katuk yang direbus. Hal ini menunjukkan bahwa data kadar vitamin $\mathrm{C}$ pada sampel daun katuk yang segar dengan daun katuk yang direbus tidak normal. Oleh karena itu untuk mengetahui apakah kadar vitamin C pada daun katuk segar dengan daun katuk yang direbus dilakukan uji Mann-Whitney yaitu uji non parametris untuk mengetahui perbedaan 2 kelompok bebas yang dimana uji normalitas tidak normal atau tidak terpenuhi.

Pengujian perbedaan dua rata-rata populasi sampel yang tidak ada korelasinya dapat dilakukan dengan uji Mann-Whitney.

Hasil pengujian Mann-Whitney ditunjukkan oleh tabel di bawah ini

Tabel 4. Uji Mann-Whitney

\begin{tabular}{ll}
\hline Test statistik & Konsentrasi \\
\hline Mann-Whitney U & 390.000 \\
Wilcoxon W & 855.000 \\
Z & -887 \\
Asymp. Sig. (2-tailed) & .375 \\
\hline
\end{tabular}

Berdasarkan tabel 4 dapat diketahui nilai U Mann-Whitney adalah 390. Nilai U pada hasil pengujian menentukan apakah 
nilai rata-rata kadar vitamin $\mathrm{C}$ pada daun katuk yang segar dengan daun katuk yang direbus berbeda atau tidak terdapat perbedaan. Nilai rata-rata kedua populasi sampel akan dikatakan berbeda apabila nilai U Mann-Whitney hasil perhitungan lebih kecil dari pada nilai U tabel. Dengan menggunakan $\alpha=0,05$ maka nilai $U$ tabel adalah 127. Apabila kita bandingkan dengan nilai $U$ hasil perhitungan maka nilai U Hitung lebih besar dari pada nilai $U$ tabel. Hal ini dapat disimpulkan bahwa tidak terdapat perbedaan yang signifikan antara rata-rata kadar vitamin $\mathrm{C}$ pada daun katuk segar dengan daun katuk yang direbus.

\section{KESIMPULAN DAN SARAN}

\section{Kesimpulan}

Pada penelitian ini dapat disimpulkan bahwa sampel daun katuk (Sauropus androgynus) pada daun katuk segar, dikukus, dan direbus mengandung vitamin C dengan kadar vitamin $\mathrm{C}$ :

a. Sampel daun katuk segar $0,0354 / \mathrm{mg}$

b. Sampel daun katuk dikukus 0

c. Sampel daun katuk direbus $0,0308 / \mathrm{mg}$

Berdasarkan hasil uji statistik metode Mann-Whitneyy didapatkan kesimpulan konsentrasi vitamin $\mathrm{C}$ pada daun katuk yang segar dan daun katuk yang direbus tidak terdapat perbedaan yang signifikan sehingga dapat dikatakan proses perebusan tidak mengurangi kadar vitmin $\mathrm{C}$ pada daun katuk secara signifikan.

\section{Saran}

Penelitian yang saya lakukan jauh dari sempurna maka diharapkan kedepannya dilakukan penelitian yang lebih sempurna dengan metode yang lain dan juga sampel yang berbeda untuk mengetahui kadar vitamin C pada sampel. Penelitian ini diharapkan dapat bermanfaat bagi pembaca, disarankan untuk meneliti kadar vitamin $\mathrm{C}$ daun katuk air rebusannya untuk melihat apakah lebih banyak kandungan vitamin $\mathrm{C}$ pada airnya a tau ekstrak daunnya.

\section{STIKes Karsa Husada Garut}

\section{DAFTAR PUSTAKA}

Arel A, Martinus B., Ningrum S.A. 2017. penetapan kadar vitamin c pada buah naga merah (hylocereus costaricensis (f.a.c. weber) britton \& rose) dengan metode spektrofotometri uv-visibel. Scientia. 7: 2087-5045.

Carr a.c., and frei b. 1999. Toward a new Recommended Dietary Allowance For Vitamin c Based on Antioxidant and Healt Effect in Humans. am. $j$. clim.nutr. 69: 1086-1107.

Cimmino L, Neel B.G, and Aifantis I. 2018. Vitamin C in Stem Cell Reprogramming and Cancer. TICB. 1423: 11 .

Damayanti ET, Kurniawati P. 2017. perbandingan metode penentuan vitamin c pada minuman kemasan menggunakan metode spektrofotometer uv-vis dan iodimetri. Prosiding Seminar Nasoinal Kimia dan Pembelajarannya. 1: 258-266. 
Deman JM, PhD.1997. kimia makanan. Bandung. ITB Bandung.

Dewi WK, Harun N, Zalfiatri Y. 2017. pemanfaatan daun katuk (sauropusn adrogynus) dalam pembuatan teh herbal dengan variasi suhu pengeringan. jom faperta. 4 :

Inayati buhari.2010.analisis kadar vitamin c dalam produk olahan buah salak (salacca zalacca) secara spektrofotometri uv-vis.fakultas ilmu kesehatan universitas islam negeri alauddin makassar:Skripsi yang dipublikasikan.

Linster CL and Van S. E. (2007). Vitamin C. Biosynthesis, recycling and degradation in mammals. FEBS $J$. 274: 1-22.

Padayatty S.J and Levine M. 2016. Vitamin C: the known and the unknown and Goldilocks. Orale Diseases. 22: 463-493.
Smirnoff N, Conklin PL, Loewus FA (2001). Biosynthesis of ascorbic acid in plants: a renaissance. Annu Rev Plant Physiol Plant Mol Biol 52: 437-467.

Taylor A. 1993. relationships between nutrition and oxidation. $j$. am. coll. nutr. 12, 138-146.

Underwood AL, Day RA. 2001. Analisis Kimia Kuantitatif. Jakarta: PT Gelora Aksara Pratama.

Winarno F.G. 1992. Kimia Pangan dan Gizi. Jakarta:PT Gramedia Pustaka Utama. 